\title{
DAMPAK PENETRASI TEKNOLOGI INFORMASI DALAM TRANSFORMASI SISTEM PENYULUHAN PERTANIAN DI INDONESIA
}

\author{
Kadhung Prayoga \\ Program Magister Penyuluhan dan Komunikasi Pembangunan, Universitas Gadjah Mada \\ Email: kadhungprayoga@gmail.com
}

\begin{abstract}
The world today has entered to the era of information society connected in a virtual world. Not only in urban areas, this phenomenon is also commonly found in rural areas. Farmers in the village have begun to take advantage of their use of information technology to meet their needs. The result is a response from the government to develop an extension system based on the use of information technology called cyber extension. Based on this phenomenon, it takes a study of the effect of what is caused by the existence of cyber extension and the theory behind it. The approach used is qualitative approach using descriptive method and discourse analysis. The data used are secondary data collected through literature study method. From the discussion is known that cyber extension has given many changes in the social structure and culture of farming communities. Changes that there are moving towards the positive but there is also a precisely cyber extension causing changes to the negative direction. However, the change is not because of the reason because according to Castell, the growing information technology such as cyber extension is present in order to provide a positive effect for human life. While Bourdeau view cyber extension as an arena in which there is a fight capital owned by farmers and extension workers. So as to form a new habitus and give birth to a different social practice prior to the extension activities conducted in the virtual space.
\end{abstract}

Keywords: information technology, cyber extension, extension, agriculture

\section{PENDAHULUAN}

Penyuluh pertanian, suatu profesi yang membawa banyak dampak signifikan dalam pembangunan pertanian di Indonesia. Berkat seorang penyuluh pertanian pula Indonesia sempat diganjar sebagai negara yang swasembada pangan. Namun, perlu diingat hal itu terjadi ketika masyarakat Indonesia masih bercorak sebagai masyarakat agraris. Transformasi di tengah masyarakat Indonesia juga berubah sangat cepat, dari yang awalnya masyarakat agraris berubah menjadi masyarakat industri dan hari ini telah memasuki era masyarakat informasi.

Masuknya masyarakat ke era informasi juga tidak lepas dari peran intervensi hp dan internet. Setelah munculnya hp dan internet, perkembangan teknologi informasi dan komunikasi menjadi semakin cepat dan menyebabkan perubahan yang begitu signifikan dalam kehidupan masyarakat saat ini. Severin (2009) menyatakan bahwa teknologi informasi berupa internet menawarkan potensi komunikasi yang lebih terdesentralisasi dan lebih demokratis dibandingkan dengan media massa yang di- tawarkan sebelumnya.

Hal ini terjadi karena dunia saat ini telah memasuki era masyarakat informasi yang terhubung dalam dunia virtual. Tak hanya di perkotaan, fenomena ini juga sudah jamak dijumpai di kawasan perdesaan. Hal ini karena teknologi digital merupakan keniscayaan, tidak dapat dibendung dan tidak pula dipungkiri kemajuannya. Petani yang ada di pelosok desa juga sudah mulai memanfaatkan kemajuan teknologi informasi dalam memenuhi kebutuhannya. Fenomena hari ini adalah sudah jamak ditemui petani yang memanfaatkan smartphone dan memanfaatkan gawainya untuk berselancar di dunia maya. Tak hanya sekedar chatting, petani juga sudah memanfaatkan internet guna mencari inforasi pertanian. Mulai dari kegiatan budidaya, pemupukan, pemanenan, hingga pemasaran suatu komoditi. Selain memberikan informasi, menurut Atrisiandy (2015) teknologi informasi juga dapat membantu jalannya penyuluhan pertanian. Karena pada zaman sekarang tidak ada kegiatan yang tidak menggunakan teknologi walaupun teknologi hanya sekedar mencari informasi untuk diri 
sendiri ataupun mencari informasi yang akan disampaikan kepada masyarakat.

Amin et. al. (2013) juga menyatakan bahwa fokus utama dari aplikasi ICT (Information and Communication Technologies) di bidang pertanian adalah memenuhi kebutuhan petani untuk informasi. Ditambahkan pula oleh Sumardjo et. al (2010) bahwa stagnansi inovasi dan informasi pertanian yang selama ini telah terjadi, diharapkan dapat diperbaiki dengan TIK melalui akses terhadap informasi pasar, input produksi, tren konsumen, pemasaran, pengelolaan penyakit dan hama/tanaman ternak, peluang pasar, harga pasar, dan lain sebagainya. Sehingga, dengan adanya pertukaran informasi melalui pemanfaatan peralatan elektronis telah merevitalisasi peranan dari layanan penyuluhan dalam penyiapan informasi, pendidikan, dan membantu dalam proses pengambilan keputusan (Alemna dan Sam, 2006)

Hingga kemudian lahirlah sebuah konsep penyuluhan di dunia virtual yang berusaha menghubungkan petani dengan penyuluh secara real time. Konsep tersebut bernama cyber extension. Cyber extension hadir dengan tujuan utama adalah untuk memberikan kemudahan bagi petani dan penyuluh dalam mengakses informasi mengingat informasi pertanian menjadi salah satu faktor kunci dalam pencapaian keberhasilan program pembangunan pertanian. Karena selama ini disitir dari Apriantono (2006), bahwa masalah utama petanis sebenarnya adalah penguasaan informasi yang masih sangat lemah. $\mathrm{Pa}-$ dahal, informasi merupakan aspek penting bagi pembangunan sosial ekonomi di pedesaan dan berpengaruh terhadap penerimaan gagasan baru dan penting untuk mengintegrasikan diri dengan dunia luar.

Beragam perubahan pun terjadi di berbagai sendi kehidupan petani dan penyuluh. Salah satunya dengan adanya teknologi informasi di sektor penyuluhan, penyuluh bisa dengan mudah mendapatkan informasi terkait beragam masalah yang dihadapi petani. Sehingga, penyuluh akan lebih mudah dalam membantu petani ketika kegiatan usaha taninya berlangsung. Dewasa ini, internet memberikan banyak kemudahan bagi penyuluh karena bisa mengatasi masalah ruang dan waktu. Hal ini berbanding terbalik ketika dahulu penyuluh masih memanfaatkan metode lama yang harus bertatap muka dan masih menggunakan media konvensional seperti televisi dan radio. Penggunaan media tersebut saat ini bisa dipahami sebagai sebuah kegagalan karena hampir tidak ada lagi informasi pertanian yang ditampilkan. Sedangkan ketika internet menginvasi, beragam informasi pertanian bisa dengan mudah ditemukan, bahkan petani bisa berkelompok berdasarkan preferensinya dalam dunia virtual. Selain itu, juga masih ada banyak perubahan lain di sektor sosio kultural yang menimpa petani dan penyuluh.

Perkembangan teknologi informasi dan komunikasi telah memberikan banyak kemudahan dan menjelma menjadi media komunikasi pertanian yang potensial dikembangkan oleh penyuluh. Adekoya (2007) bahkan menjelaskan dengan adanya teknologi informasi dapat memberikan layanan penyuluhan dari berbagai sektor pertanian dan memainkan peranan penting dalam pembangunan pedesaan sehingga mnghasilkan berbagai perubahan. Sehingga penulisan paper ini bertujuan untuk memberikan gambaran dan informasi mengenai perubahan sosio kultural apa saja yang terjadi akibat cyber extension dan kaitannya dengan teori yang ada.

\section{METODE PENELITIAN}

Paper ini bersifat deskriptif dengan menggunakan sebuah pendekatan kualitatif. Sedangkan, metode yang digunakan adalah metode deskriptif dan analisis wacana. Penulisan paper ini berusaha untuk menjelaskan perubahan yang disebabkan oleh adanya cyber extension dan teori yang melatarbelakanginya. Teknik pengumpulan datanya sendiri menggunakan metode studi pustaka untuk mendapatkan data-data sekunder. Data sekunder dalam penulisan paper ini berupa bahan-bahan tertulis yang berasal dari penelitian terdahulu, jurnal, buku, tesis, disertasi, dan berbagai informasi digital yang ada di internet. Analisis menggunakan interpretasi peneliti dengan mengacu pada berbagai literatur atau referensi yang relevan dengan objek kajian dalam penulisan paper ini.

Langkah pertama ialah pengumpulan berbagai data sekunder berupa hasil penelitian seperti skripsi, tesis, jurnal, disertasi, maupun buku-buku mengenai cyber extension, teori Pierre Baudrillard, dan teori Manuel Castell. Kemudian data sekunder tersebut dipelajari, diringkas, serta disusun menjadi sebuah ringkasan studi pustaka yang relevan. Selanjutnya dilakukan sintesis dan analisis dari hasil ringkasan studi pustaka. Terakhir ialah penarikan hubungan dari semua hal yang telah dilakukan sehingga 
memunculkan sebuah kerangka teoritis yang menjadi dasar perumusan masalah bagi penelitian yang akan dilakukan.

\section{HASIL DAN PEMBAHASAN}

Dalam perkembangan teknologi informasi, sektor penyuluhan pertanian juga terkena dampak dari keberadaannya. Beragam perubahan baik dari sisi kultural, sosial, maupun ekonomi terjadi. Bahkan perubahan tersebut telah menyeluruh hingga tataran sistem. Tak hanya instansi penyelenggara seperti Kementerian Pertanian, penyuluh yang notabene sebagai ujung tombank penyuluhan beserta petani sebagai mitra kerja penyuluh juga mengalami perubahan yang sangat drastis bila dibandingkan sebelum adanya teknologi informasi.

\section{Cyber Extensian: Transformasi Baru Sektor Penyuluhan di Era Digital}

Dewasa ini, berkenaan dengan perkembangan teknologi informasi maka muncullah suatu paradigma baru bahwasanya penyuluhan tak lagi dilakukan di lapang dan mengharuskan penyuluh dan petani bertatap muka. Telah muncul suatu perubahan paradigma bahwasanya petani dan penyuluh harus bisa berinteraksi di ruang virtual. Penyuluh harus mampu memberikan layanan real time, cepat, dan akurat kepada petani. Dan lewat sistem penyuluhan yang berbasis internet, petani diharapkan juga bisa untuk bertukar informasi dan permasalahan dengan petani lain yang berada di luar wilayahnya. $C y$ ber extension hadir dengan harapan bisa memutus batasan waktu, ruang, dan jarak. Bahkan menurut Fatimah (2013) cyber extension merupakan pintu masuk menuju smart extension.

Sedangkan penelitian Slamet (2003) dalam Anwas (2009) dan Hafsah (2009), menyatakan sekitar 80 persen masyarakat Indonesia hidup di pedesaan dan hingga sekarang masih banyak rakyat yang belum cukup tersentuh oleh kesempatan berpartisipasi dalam pembangunan, termasuk menikmati hasil pembangunan. Hal ini terjadi karena masih minimnya dan kurangnya rasa keadilan terhadap informasi yang diperoleh petani di pedesaan. Sehingga, dengan adanya cyber extension sangat memungkinkan mereka bisa terlibat langsung dalam kegiatan pembangunan dan dalam berusaha memperbaiki taraf hidupnya. Dikutip dari Usman et al. (2012) teknologi informasi memang sudah harus diikutsertakan kedalam agenda pembangunan perta- nian. Kesadaran harus ditumbuhkan dalam diri kalangan petani muda dan setengah baya tentang ketersediaan informasi berbasais teknologi informasi guna meningkatkan partisipasi dan inisiatif mereka.

Sehingga, cyber extension menjadi salah satu sub sitem yang penting dalam pengembangan e-agribisnis karena cyber extension bertugas untuk menghantarkan informasi kepada petani. Informasi saat ini adalah faktor pelancar dan katalisator dalam pembangunan sektor pertanian. Bahkan Suryantini (2004) mengemukakan bahwa informasi pertanian memegang peranan penting dalam proses pembangunan pertanian. Tersedianya berbagai sumber informasi yang akan menyebarkan atau menyampaikan informasi teknologi pertanian dapat mempercepat kemajuan usaha pertanian di pedesaan.

Dikuatkan oleh Sharma (2006) dan Mardikanto (1993), pengimplementasian teknologi informasi dan komunikasi seperti cyber extension di sektor pertanian merupakan salah satu mekanisme pengembangan model pemberdayaan dan penyebarluasan informasi inovasi pertanian secara terprogram, tepat waktu, dan relevan dalam mendukung proses pengambilan keputusan petani dan penyuluh yang akan menentukan keberhasilan penyuluhan. Subejo (2011) menguatkan argument ini bahwa pengembangan media yang berbasis teknologi informasi adalah salah satu alternatif untuk menjamin kecepatan dan ketepatan penyebaran informasi teknologi baru di bidang pertanian.

Kedepan dalam sub sistem cyber extension penyuluh juga harus sudah memisahkan materi atau pesan yang akan disuluhkan kepada petani. Tidak hanya informasi mengenai on farm namun juga merambah informasi dari sektor hulu hingga hilir. Informasi mencakup bagaimana menjual produknya di era virtual semacam ini, penambahan added value dari hasil pertanian, kelembagaan, hingga pemanfaatan kearifan lokal di sektor petanian. Sementara itu, Havelock dalam Mardikanto (1993) juga menyatakan bahwa agar kegiatan penyuluhan bisa berjalan baik maka sebaiknya penyuluh bisa memisahkan pesannya kedalam dua hal yaitu pesan ideologis dan pesan informatif.

Keuntungan yang potensial dari komunikasi cyber extension adalah ketersediaan yang secara terus menerus, kekayaan informasi (informasi nyaris tanpa batas), jangkauan wilayah internasional secara instan, pendekatan yang 
berorientasi kepada penerima, bersifat pribadi (individual), dan menghemat biaya, waktu dan tenaga (Adekoya, 2007). Kehadiran cyber extension dapat mendukung fungsi dan peran penyuluh dalam menyediakan dan mempercepat arus penyebaran informasi dengan memanfaatkan jaringan internet untuk menjembatani pelaku utama pertanian (petani) dengan lembaga penelitian dan pelaku usaha.

Hal tersebut diatas bisa terjadi karena memang fokus utama dari cyber etension pada dasarnya adalah untuk memenuhi kebutuhan petani akan informasi. Kebutuhan informasi oleh petani biasanya adalah seputar informasi pasar, teknologi pertanian termasuk teknologi pasca panen, pembangunan pertanian pada umumnya, cuaca, contoh-contoh (best practices), informasi hama, informasi kesesuaian lahan, dan lain sebagainya yang terkait dengan usaha budi daya pertanian. Ketika informasi tersebut tersedia dengan mudah, murah dan mudah dimengerti, serta ada contoh-contoh keberhasilan, petani akan cenderung untuk berminat dapat mengikuti. Sehingga, petani perlu memanfaatkan dengan optimal teknologi-teknologi alternatif tersebut sehingga mereka tidak ketinggalan informasi dan dapat mengembangkan pertaniannya mulai hulu hingga hilir (Van Den Ban dan Hawkins, 1999). Sehingga, informasi yang didapatkan dapat menjadi acuan pengembangan dalam budidaya maupun pengolahan pasca panen. Tentu saja hal yang kita harapkan adalah peningkatan produktivitas dan nilai tambah yang merupakan ciri pertanian modern dapat tercapai.

Jadi menurut Mulyandari et. al. (2010), sebuah sistem cyber extension memberikan dukungan pada keseluruhan pengembangan termasuk produksi, manajemen, pemasaran, dan kegiatan pembangunan perdesaan lainnya. Model komunikasi cyber extension mengumpulkan atau memusatkan informasi yang diterima oleh petani dari berbagai sumber yang berbeda maupun yang sama dan disederhanakan dalam bahasa lokal disertai dengan teks dan ilustrasi audio visual yang dapat disajikan atau diperlihatkan kepada seluruh masyarakat desa khususnya petani semacam papan pengumuman (bulletin board) pada kios atau pusat informasi pertanian.

\section{Perubahan Sosio-Kultural di Sektor Penyuluhan Pertanian}

Jika dahulu penyuluhan identik dengan kegiatan lapang yang mengharuskan tatap muka antara petani dan penyuluh maka hari ini paradigm tersebut telah bergeser. Kemajuan teknologi informasi menghasilkan kemudahan bagi penyuluh dan petani, mereka kini tak lagi harus bertemu di sawah melainkan sudah bisa berinteraksi secara intens lewat beragam medium. Medium-medium seperti website, media sosial, aplikasi digital pertanian yang notabene merupakan produk dari tekonologi informasi menjadikan penyuluhan pertanian kini telah sampai di era virtual. Penyuluh dan petani telah terkoneksi dalam sebuah ruang maya yang tidak mengenal batasan tempat dan waktu. Sehingga, kegiatan penyuluhan juga bisa lebih efektif dan efisien.

Di penyuluhan pertanain era sekarang, petani tak lagi berposisi sebagai subjek penyuluhan, namun sudah bergeser menjadi objek. Petani bisa dengan bebas untuk menyuarakan pendapatnya dan memberikan masukan kepada penyuluh. Bahkan petani tidak hanya terhubung dengan penyuluh di daerahnya namun juga bisa berinteraksi dengan penyuluh dan petani yang ada di wilayah lain. Geografis wilayah tak lagi menjadi masalah, bahkan petani juga bisa berinteraksi kapanpun dia membutuhkan informasi. Tak lagi seperti dulu yang harus menunggu seminggu sekali untuk bisa bertemu dengan penyuluh.

Penyuluh dengan bantuan teknologi informasi mempunyai kuasa untuk menentukan nasib dirinya. Petani bisa memilih informasi apa yang dibutuhkan dan memberikan masukan serta kritikan terhadap sistem dan teknis penyuluhan yang sedang berlangsung. Dari sini bisa dilihat bahwasanya teknologi informasi telah mendukung terciptanya sistem bottom up dalam pelaksaan kegiatan penyuluhan pertanian di Indonesia. Hal ini tentu jauh berbeda ketika dulu sebelum adanya teknologi informasi, petani harus mengikuti semua anjuran penyuluh dan tidak boleh menyela. Konsep top down dahulu telah membungkam mulut petani dan membatasi ruang geraknya. Petani juga hanya bisa berinteraksi dalam waktu yang terbatas dan dengan penuh tekanan. Akibatnya kegiatan usaha budi daya pertanian juga tidak sesuai dengan kebutuhan petani.

Sebelum penetrasi yang massif dari teknologi informasi seperti hari ini, dulu sistem penyuluhan adalah top down dimana semua kegiatan penyuluhan mulai dari perencanaan, penentuan materi dan metode, hingga evaluasi semua ditentukan oleh pemerintah pusat. Pemerintah daerah tidak memiliki kewenangan untuk 
mengelola daerahnya sendiri. Masyarakat juga tidak diikutsertakan dalam kegiatan penyuluhan. Dalam budaya top down, masyarakat tani hanyalah objek pembangunan yang bodoh sehingga perlu penyuluhan. Masyarakat tidak pernah dilihat sebagai subjek pembangunan pertanian sehingga tingkat partisipasi terhadap pengembangan sektor pertanian juga rendah. Senada dengan hal ini Bourgeois et. al. (2013) menyatakan bahwa penyuluh bekerja sebatas sebagai penyampai pesan pemerintah dan tidak memberikan serta menyediakan jasa yang memadai.

Paradigma penyuluhan pertanian yang dominan pada waktu itu juga menekankan pada pendekatan yang sangat sentralistik, dengan dukungan dana dari pusat yang bersumber dari negara donor, statis dan mekanis, masing-masing pihak berperan secara spesifik sehingga kurang luwes, pola komunikasi linear, bahkan cenderung bersifat instruksional dengan sistem target yang kaku. Akibatnya adalah masyarakat tani tidak memiliki ruang untuk menyuarakan kebutuhannya. Pemerintah memposisikan diri sebagai pihak yang serba tahu akan keinginan dan kebutuhan petani. Petani tidak memiliki kesempatan untuk menentukan sendiri kegiatan pertanian yang akan diambil karena memang pemerintah hanya memfokuskan petani untuk menanam satu komoditas saja. Penyuluhan pertanian tidak lagi berbasis pada proses belajar melainkan pada proses pemaksaan untuk menggunakan teknologi tertentu demi tercapainya tujuan tunggal pemerintah. Tujuan masyarakat tanipun diabaikan karena yang menjadi fokus adalah tujuan nasional bukan untuk tujuan kemakmuran petani.

Hasil dari semua itu menurut Chambers (1993) menghasilkan suatu ketergantungan yang tinggi oleh pihak daerah kepada pusat dan pusat kepada negara donor, terkotak-kotak antara subsektor dalam agribisnis dan tidak sinergis. Bahkan efeknya terasa sampai hari ini, ketika desentralisasi diberlakukan pemerintah daerah masih kebingungan menentukan prioritas pembangunan pertaniannya. Kegiatan penyuluhan juga semacam kehilangan arah, tidak mampu lagi mempengaruhi petani untuk menerapkan suatu inovasi. Penyuluh yang dahulu sangat powerfull hari ini menjadi tidak berdaya karena memang sudah terbiasa dengan sistem. Dengan sistem top down, penyuluh selalu diuntungkan karena tidak perlu memikirkan rencana penyuluhan sehingga penyuluh juga kurang mengembangkan kapasitas dirinya. Sedangkan ketika hari ini sudut pan- dang penyuluhan menjadi bottom up, penyuluh tidak mampu beradaptasi dan yang terjadi adalah penyuluh semakin ditinggalkan oleh petani karena dirasa gagal dalam menyediakan informasi bagi mereka.

Penyuluhan yang top down juga menyebabkan menurunnya kreativitas petani dan menumbuhkan sikap ketergantungan pada bantuan pemerintah. Selama ini, penyuluhan pertanian bukan bertujuan mengembangkan kapasitas petani namun hanya memberikan sumbangan kepada petani. Akibatnya petani menjadi tergantung dan ketika diberi dana untuk berdaya mereka tidak mampu menggunakannya karena mereka juga tidak bisa mengidentifikasi masalah serta potensi yang dimiliki. Bahkan, karena rendahnya penguatan kapasitas petani menyebabkan kreativitas dan kearifan lembaga-lembaga lokal tidak berkembang bahkan banyak yang hilang. Hal ini sejalan dengan apa yang diungkapkan oleh Kottak (1988) dan Uphoff (1988) bahwa pendekatan pembangunan pertanian yang tidak mengutamakan manusianya telah menyebabkan kurang berfungsi atau matinya kelembagaan lokal, lemahnya kemandirian petani, serta keberlanjutan pembangunan pertanian bisa terancam atau mengalami kegagalan.

Senada dengan hal ini Rangkuti (2010) melihat kebijakan pemerintah yang mengacu kepada model komunikasi linier (satu arah) dan berbentuk vertikal dari atas ke bawah mengakibatkan terjadi kecenderungan melambatnya adopsi inovasi teknologi pertanian dalam peningkatan produksi, seperti terlihat dari gejala stagnasi atau pelandaian produktivitas berbagai produksi komoditas pertanian dan pendapatan serta kesejahteraan petani di pedesaan pada hari ini. Penyuluhan sebelum era informasi menghasilkan produk petani yang menjadi terbiasa dan tidak lagi kreatif. Petani sekarang hanya menunggu karena tidak mengetahui apa yang seharusnya dilakukan. Petani menjadi lebih suka mendapatkan instruksi yang jelas dan diberi arahan untuk mencapai target apa daripada harus memikirkan dirinya sendiri.

Dan hal ini berbeda ketika dalam era informasi penyuluhan dilakukan dengan sistem bottom up. Sistem ini mensyaratkan partisipasi aktif dari masyarakat untuk bisa mengidentifikasi masalah dan potensi yang mereka miliki sehingga bisa memberikan masukan terhadap pelaksanaan program pembangunan pertanian. Dan hari ini partisipasi tersebut dapat dilihat dengan 
mudahnya petani dan masyarakat untuk memberikan pendapat dan bertukar pikiran dengan penyuluh lewat dunia cyber. Teknologi informasi sangat memudahkan petani untuk menyuarakan pendapat dan kehendaknya. Hal ini juga berkaca pada hemat Rhoades dan Bebbington (1995) serta Arce dan Long (1992) bahwa penduduk setempat sebenarnya adalah pencipta dari solusi-solusi yang dihasilkannya sendiri dalam menghadapi berbagai tantangan dan masalah yang timbul sebagai konsekuensi dari penerapan teknologi yang baru, tidak melulu sebagai penerima yang pasif. Penyuluhan hanya membantu penduduk setempat tersebut untuk menciptakan solusi bukan sebagai pihak yang memberi solusi.

Di era informasi seperti ini, pemerintah sebagai pemegang kendali penyuluhan pertanian tidak lagi bisa memposisikan diri sebagai pihak yang serba tahu akan keinginan dan kebutuhan petani. Hal ini karena petani sudah memiliki akses terhadap informasi dan mudahnya petani dalam memilah informasi. Penyuluh hari ini juga tak lagi berperan sebagai yang paling berkuasa namun lebih berganti fungsi sebagai fasilitator dan penyaring informasi. Penyuluh dibutuhkan masyarakat bukan lagi sebagai sumber tunggal informasi namun lebih kepada bagaimana membantu petani untuk memilih informasi yang paling dibutuhkan. Kemudahan akses informasi ini juga menjadikan penyuluh harus lebih selangkah di depan dari petani dengan jalan membuat rencana penyuluhan, mencari informasi terbaru dan menguasai teknologi informasi dalam rangka untuk penguatan kapasitas dirinya. Proses adaptasi dari penyuluh ini perlu jika mereka tidak ingin ditinggalkan oleh petani.

Bahkan jika dahulu petani kita cenderung malas mencari informasi karena semua sudah disediakan oleh penyuluh, maka hari ini masyarakat tanilah yang harus aktif sendiri untuk mencari informasi. Dan jika petani tidak mampu untuk bergerak aktif dan mandiri dalam mencari informasi maka yang terjadi adalah kalah bersaing dalam kontestasi global. Ketika petani di belahan dunia lain sudah mampu menggunakan drone, membuat semangka dengan berbagai bentuk, dan berbagai inovasi lainnya jika petani kita tidak mau mencari inovasi tersebut maka yang terjadi adalah pertanain Indonesia akan semakin tidak berdaya. Dari sini bisa dilihat bahwa harus terjadi perubahan pola pikir dan budaya petani dari yang awalnya diberi maka kini harus mencari. Teknologi informasi di satu sisi akan mem- berikan kemudahan bagi mereka yang mampu menguasainya, namun juga akan menyebabkan petani kita semakin tertinggal jika tidak mampu menguasainya.

Penelitian Sumardjo (1999) juga menunjukkan bahwa pola komunikasi yang konvergen seperti ini lebih efektif sebagai paradigma komunikasi pada penyuluhan dalam menghadapi era globalisasi. Dengan model konvergensi komunikasi ini, terjadi keterpaduan antara kebutuhan petani dengan kebutuhan pihak-pihak terkait seperti peneliti, penyuluh dan pelaku usaha. Kesinambungan dalam inovasi petanian tersebut memacu masing-masing pihak untuk berinteraksi dan berkomunikasi secara proaktif dan antisipatif melalui berbagi pengetahuan (knowledge sharing) yang saling mendukung dalam upaya pemenuhan kebutuhan masing-masing pihak.

Berdasarkan hal tersebut, maka sangat jelas bahwa penyuluhan tidak lagi dipandang hanya sebagai transfer of technology semata, melainkan sudah saatnya beralih pada farmer participation dan porsi terbesar setiap kebijaksanaan pertanian adalah membangun kemampuan petani (kemampuan leadership, kualitas hidup dan pemberdayaan petani) (Slamet 2003). Penyuluhan yang seperti ini menurut Rahadian (2010) dapat dipandang dari sudut proses rekayasa atau proses transformasi sosial, ekonomi dan politik khususnya terhadap masyarakat pedesaan yang terutama bermatapencaharian pokok di sektor pertanian yang berpendapatan rendah serta tertinggal.

Namun dampak positif juga dirasakan penyuluh pertanian karena dengan berkembangnya teknologi informasi dan multimedia yang begitu cepat maka akan berdampak pada peningkatan terhadap kualitas sumber daya tenaga penyuluh. Penyuluh pertanian dituntut untuk memahami teknologi informasi dan komunikasi selain dari ilmu-ilmu mengenai pertanian. Oleh sebab itu para penyuluh juga harus mampu mengaplikasikan teknologi informasi sebelum mereka melakukan penyuluhan-penyuluhan. Sehingga pada akhirnya penyuluhan berfungsi untuk menjembatani kesenjangan antara praktek yang harus atau biasa dijalankan oleh petani dengan pengetahuan dan teknologi yang selalu berkembang yang menjadi kebutuhan petani tersebut. Penyuluh pertanian akan membimbing petani dengan pengetahuan dan teknologi yang sedang berkembang untuk diterapkan kepada petani dalam usaha taninya. Sebaliknya jika petani mem- 
punyai masalah yang memerlukan pemecahan para ahli, seperti kegagalan panen akibat serangan hama/keadaan tanahnya dapat disampaikan kepada para ahli melalui penyuluh. Dalam era baru pertanian, penyuluh lapangan juga dituntut memiliki fungsi paling tidak dalam tiga hal yaitu transfer teknologi (technology transfer), fasilitasi (facilitation) dan penasehat (advisory work).

Hal ini senada dengan pendapat Damanik dan Meilvis (2011) yang menjelaskan bahwa penerapan cyber extension bukan berarti meniadakan peran penyuluh, bahkan penyuluh diharapkan dapat lebih meningkatkan kompetensinya agar dapat masuk ke dalam area cyber dalam melaksanakan tugasnya, dan ini membutuhkan usaha dan dukungan dari semua yang terlibat. Seorang Atrisiandy (2015) juga menyatakan bahwa tantangan kegiatan penyuluhan di lapangan semakin berat, sehingga jika penyuluhan pertanian sebagai penyedia public goods tidak bisa berperan dengan baik akan semakin ditinggalkan oleh penguna tradisionalnya. Zaman telah berubah, maka sudah sewajarnya jika penyuluh pertanian juga ikut berbenah. Penyuluh pertanian sebagai ujung tombak pembangunan pertanian harus sudah familiar dengan internet agar bisa mengimbangi gerak petani. Internet di satu sisi bisa memudahkan petani, namun di sisi lain bisa membingungkan petani karena adanya ledakan dan tsunami informasi. Disini penyuluh harus menjadi seorang gatekeeper yang mampu membantu petani dalam memilah informasi.

Didukung oleh penelitian Anwas (2010), bahwa tuntutan petani terhadap penyuluh untuk melakukan perubahan dalam menerapkan inovasi atau teknologi baru secara nyata berpengaruh tidak langsung terhadap kompetensi penyuluh melalui pemanfaatan media. Tuntutan petani untuk perubahan dalam penyuluhan dipandang sebagai sebuah tantangan. Semakin rumitnya tuntutan atau tantangan petani seiring perkembangan zaman, menuntut kesadaran penyuluh untuk terus belajar. Untuk memenuhi tantangan tersebut, penyuluh dituntut untuk meningkatkan kemampuannya melalui proses belajar. Sebaliknya penyuluh yang menganggap tuntutan tersebut sebagai masalah, sehingga kurang terdorong untuk belajar, akibatnya kemampuannya tidak bisa memenuhi harapan petani.

Perubahan kultur lainnya adalah beralihnya karakteristik petani subsisten menjadi petani komersial. Jika dulu petani cenderung bertani hanya untuk memenuhi kebutuhannya, maka hari ini dengan keterdedahan informasi etani akan cenderung menanam komoditas yang berorientasi pasar. Pola pikir petani akan berubah dan berorientasi pasar, tidak lagi sesederhana dulu. Hal ini terjadi karena cyber extension dapat membantu membuka wawasan para petani dalam mengembangkan usahataninya dengan melihat perkembangan pertanian di daerah lain, bahkan di negara lain. Dengan kemudahan ini petani bisa menilai komoditas apa yang sedang laku di pasaran sehingga akan ada proses imitasi atau meniru petani di daerah lain. Baik itu komoditas yang ditanam maupun cara budidayanya.

Pranadji (1995) juga menjelaskan tentang transformasi ekonomi pertanian yang berciri budaya agribisnis tradisional/subsisten ke yang berciri budaya agribisnis modern/komersial. Tansformasi agribisnis di pedesaan merupakan respon dan antisipasi terhadap tuntutan kemajuan untuk hidup lebih baik, dan globalisasi pasar. Dengan demikian proses transformasi harus dipandang sebagai gejala alamiah dan proses aktif dari sistem sosial yang berada di belakang kegiatan agribisnis di pedesaan karena adanya kemajuan teknologi informasi. Cyber extension juga berfungsi untuk memperbaiki aksesibilitas petani dengan cepat terhadap informasi pasar, input produksi, tren konsumen, yang secara positif berdampak pada kualitas dan kuantitas produksi mereka.

Dahulu kultur berbagi masih belum membudaya maka dengan kemudahan teknologi informasi semakin banyak petani maupun penyuluh yang bertukar dan berbagi informasi. Lewat grup yang mereka bentuk di duni maya, beragam info coba mereka bagikan. Mulai dari cara budidaya, komoditas unggulan, pengolahan hasil panen, hingga kegiatan pemasran yang sudah mereka lakukan. Disini muncul kultur berbagi informasi dan pengetahuan untuk mempermudah akses dan pengelolaan informasi oleh banyak pihak.

Selanjutnya adalah munculnya kebiasaan di instansi pemerintah yang bergerak di sektor pertanian untuk tertib dalam mencatat data. Pendokumentasian informasi atau data menajdi suatu yang mutlak dalam pengemaabngan cyber extension karena hal ini akan memudahkan mengelompokkan informasi. Selain itu juga karena cyber extension mengharuskan semua stakeholders bisa mengakses apapun informasi yang dibutuhkan. 
Tabel 1. Perubahan Positif Sosio-Kultural yang Terjadi

Top Down (Sebelum Era Informasi)
Penyuluhan identik dengan kegiatan lapang yang
mengharuskan tatap muka antara petani dan pen-
yuluh.
Petani adalah subjek yang dianggap tidak memiliki
pengetahuan
Petani harus mengikuti semua anjuran penyuluh
dan tidak boleh menyela.
Petani hanya bisa berhubungan dengan penyuluh
dengan jangka waktu yang terbatas.
Bottom Up (Dengan Bantuan Teknologi Informasi)

Penyuluh dan petani, mereka kini tak lagi harus bertemu di sawah melainkan sudah bisa berinteraksi secara intens lewat beragam medium sebagai hasi dari kemajuan teknologi informasi seperti media sosial, aplikasi digital, sms, video conference, dan sebagainya.

Di penyuluhan pertanain era sekarang, petani tak lagi berposisi sebagai subjek penyuluhan, namun sudah bergeser menjadi objek.

Petani bisa dengan bebas untuk menyuarakan pendapatnya dan memberikan masukan kepada penyuluh.

Petani tidak hanya terhubung dengan penyuluh di daerahnya namun juga bisa berinteraksi dengan penyuluh dan petani yang ada di wilayah lain.

Semua informasi berasal dari penyuluh meskipun Petani bisa memilih informasi apa yang dibutuhkan dan informasi tersebut tidak dibutuhkan oleh petani. memberikan masukan serta kritikan terhadap sistem dan teknis penyuluhan yang sedang berlangsung.

Pola komunikasi linear, bahkan cenderung bersifat instruksional dengan sistem target yang kaku.

Pola komunikasi dailogis karena ada timbal balik dari petani terhadap penyuluh.

Semua kegiatan penyuluhan mulai dari peren- Sistem ini mensyaratkan partisipasi aktif dari mascanaan, penentuan materi dan metode, hingga yarakat untuk bisa mengidentifikasi masalah dan poevaluasi semua ditentukan oleh pemerintah pu- tensi yang mereka miliki sehingga bisa memberikan sat. Pemerintah daerah maupun masyarakat tidak masukan terhadap pelaksanaan program pembangumemiliki kewenangan untuk mengelola daerahnya nan pertanian.

sendiri.

Penyuluh dahulu sangat powerfull dan selalu di- Penyuluh harus lebih selangkah di depan dari petani untungkan karena tidak perlu memikirkan ren- dengan jalan membuat rencana penyuluhan, mencari cana penyuluhan sehingga penyuluh juga kurang informasi terbaru dan menguasai teknologi informasi mengembangkan kapasitas dirinya.

dalam rangka untuk penguatan kapasitas dirinya.

Penyuluh adalah sumber obat dari segala masalah petani

Penyuluh dibutuhkan masyarakat bukan lagi sebagai sumber tunggal informasi namun lebih kepada bagaimana membantu petani untuk memilih informasi yang paling dibutuhkan.

Pemerintah memposisikan diri sebagai pihak yang Petani memiliki kuasa untuk mengatur dirinya sendiri. serba tahu akan keinginan dan kebutuhan petani. Petani tidak memiliki kesempatan untuk menentukan sendiri kegiatan pertanian yang akan diambil

Penyuluh kurang bisa mengakselerasikan kemam- Penyuluh lebih mudah mengembangkan diri. puannya.

Penyuluh cenderung hanya mengerti materi on farm karena tidak ada pengembangan diri. Kondisi hulu-hilir cenderung diabaikan.

Penyuluh pertanian dituntut untuk memahami teknologi informasi dan komunikasi selain dari ilmu-ilmu mengenai pertanian.

Petani menjunjung tinggi budaya subsiten.

Petani bermental komersial.

Baik petani atau penyuluh akan cenderung tidak Munculnya budaya sharing informasi. memberitahu orang lain jika merasa memiliki informasi yang dianggap penting karena mereka merasa takut untuk tersaingi.

Kurang adanya budaya untuk mencatat hal-hal Budaya pendokumentasian data menjadi lebih tertib penting, pengalaman, atau pengetahuan lokal.

dan tertata.

Sumber: Penulis, 2017 
Selain perubahan ke arah postif seperti yang dijelaskan diatas, pengaruh negative juga ditemui ketika teknologi informasi telah menginvasi kegiatan penyuluhan pertanian. Dengan adanya teknologi informasi petani sudah mulai terbiasa untuk mencari informasi sendiri sehingga interaksi antara petani dengan penyuluh maupun petani dengan petani mulai berkurang. Akibatnya tentu saja gotong royong juga mulai memudar dan rasa saling membutuhkan juga mulai hilang. Petani merasa tidak lagi membutuhkan penyuluh dan petani lain karena memang dengan kecanggihan teknologi informasi semua informasi sudah bisa mereka cari.

Yang kedua adalah hilangnya kegiatan-kegiatan musyawarah guna mencari solusi dari permasalahan yang dihadapi oleh petani. Jika sebelum era informasi petani terbiasa bercerita di forum tentang suatu masalah dan petani lain mencoba untuk memikirkannya maka hari ini hal itu suah akan jarang ditemui. Interaksi yang terjadi di dunia nyata sudah mulai tergantikan oleh interaksi di dunia maya. Kurangnya intensitas pertemuan antara petani dan penyuluh juga menyebabkan hilangnya sense of belonging dari diri petani terhadap kegiatan penyuluhan. Penyuluhan tidak lagi dipandang petani sebagai sesuatu yang dibutuhkan namun terjadi perubahan sudut pandang bahwa penyuluhanlah yang sekarang membutuhkan petani. Munculnya pemikiran ini karena memang didasari kemudahan petani dalam mengakses informasi dari berbagai sumber.
Padahal interaksi sosial merupakan sesuatu yang vital, seperti dikutip dari Herlina (2014) penyuluh dan petani dulu sebelum adanya cyber extension juga intens dalam membangun interaksi sosial. Hal yang dilakukan adalah sering melakukan diskusi dengan petani dalam menentukan kegiatan apa yang diperlukan untuk upaya peningkatan usahatani. Pentingnya interaksi antara petani dan penyuluh ini juga disoroti oleh Johnson dan Doyel (1986) yang mengatakan bahwa di dalam masyarakat, interaksi adalah suatu hubungan timbal balik antara individu dengan individu lainnya, individu dengan kelompok dan sebaliknya. Interaksi sosial memungkinkan masyarakat berproses sedemikian rupa sehingga membangun suatu pola hubungan sosial. Hubungan sosial yang dimaksud dapat berupa hubungan antara individu yang satu dengan individu lainnya, antara kelompok yang satu dengan kelompok lainnya, maupun antara kelompok dengan individu. Proses interaksi dapat terjadi bila antara dua individu atau kelompok terdapat kontak sosial dan komunikasi.

Hal ini senada dengan pendapat Adekoya (2007) dan Reddy (2005) bahwa dengan adanya teknologi informasi di sektor penyuluhan telah menyebabkan adanya perubahan budaya petani. Petani hari ini yang kita lihat lebih bersifat soliter daripada komunal. Mereka semakin sulit untuk dapat dikumpulkan pada satu tempat dan waktu tertentu. Begitupula dengan penyuluh, penyuluh juga menjadi semakin jarang untuk turun ke lapang karena memang petani bisa

Tabel 2. Perubahan Negatif Sosio-Kultural yang Terjadi

\begin{tabular}{|c|c|}
\hline Top Down (Sebelum Era Informasi) & $\begin{array}{l}\text { Bottom Up (Dengan Bantuan Teknologi } \\
\text { Informasi) }\end{array}$ \\
\hline $\begin{array}{l}\text { Petani mengedepankan prinsip hidup untuk hidup } \\
\text { bersama, menanggung maslah bersama, dan men- } \\
\text { cari solusi bersama (komunal) }\end{array}$ & $\begin{array}{l}\text { Baik petani maupun penyuluh menjadi so- } \\
\text { liter atau individual. }\end{array}$ \\
\hline $\begin{array}{l}\text { Petani akan sangat intens dalam berinteraksi den- } \\
\text { gan petani lain maupun dengan penyuluh karena } \\
\text { memang informasi sulit untuk didapatkan. }\end{array}$ & $\begin{array}{l}\text { Berkurang atau memudarnya interaksi sosial } \\
\text { baik antara petani dengan pnyuluh maupun } \\
\text { petani dengan petani. }\end{array}$ \\
\hline $\begin{array}{l}\text { Penyuluhan adalah sesuatu yang sangat dibutuh- } \\
\text { kan karena menajdi satu-satunya sumber infor- } \\
\text { masi bagi petani dan masyarakat yang berada di } \\
\text { kawasan perdesaan. }\end{array}$ & $\begin{array}{l}\text { Petani merasa tidak lagi membutuhkan } \\
\text { penyuluh dan kegiatan penyuluhan karena } \\
\text { semua informasi yang dibutuhkan sudah ada. }\end{array}$ \\
\hline $\begin{array}{l}\text { Petani dan penyuluh sering melakukan forum } \\
\text { musyawarah untuk mengidentifikasi permasalah- } \\
\text { an dan informasi apa yang dibutuhkan oleh petani. }\end{array}$ & $\begin{array}{l}\text { Memudarnya budaya dan kegiatan musy- } \\
\text { awarah guna mencari solusi dari permasala- } \\
\text { han yang dihadapi oleh petani. }\end{array}$ \\
\hline
\end{tabular}
Sumber: Penulis, 2017 
dikondisikan hanya lewat sebuah grup di media sosial. Hal ini terbukti dengan semakin banyaknya grup di facebook, whats app atau line yang isinya adalah petani dan penyuluh. Problematika penyuluhan hari ini dalam mengumpulkan masyarakat bukan lagi pada persoalan beraneka ragamnya kegiatan petani atau waktu penyuluhan yang mengganggu kegiatan tersebut. Masalah hari ini yang muncul adalah petani mulai terbiasa untuk melakukan mobilitas sosial itu di ruang maya, tidak lagi di dunia nyata.

\section{Kaitan Dampak Perubahan Sosio-Kultural Pemanfaatan Cyber Extension dengan Teori (Pierre Bourdeau dan Manuel Castell)}

Pembentukan cyber extension jika mengacu pada pemikiran Castell (2000) maka merupakan sebuah efek yang positif dengan adanya teknologi informasi. Media dan teknologi komunikasi telah membawa masyarakat kepada era revolusi informasi. Teknologi komunikasi membolehkan manusia berhubung secara global membawa kepada bentuk sosial ekonomi baru. Di sini cyber extension telah menyediakan wahana untuk local empowerment dan membangkitkan sense of community.

Cyber extension dapat membentuk sebuah masyarakat jejaring (network society) yang secara bersamaan menyatu dalam interaksi sosial di ruang cyber untuk membentuk struktur sosial yang baru, sebagai faktor yang mendasari lahirnya masyarakat baru (new society). Disini globalisasi teknologi informasi dapat dipahami sebagai peningkatan kapasitas teknologi, organisasi, serta kelembagaan dari komponen inti sistem tertentu sehingga bisa bekerja pada satu waktu yang bersamaan dan menjangkau skala luas mencakup seluruh jagat raya.

Sedangkan dari sudut pandang Boudeau, pembentukan cyber extension merupakan bentuk dari pembentukan arena. Cyber extension sebagai sebuah arena menemukan banyak stakeholders, seperti petani, penyuluh, instansi pemerintah, dan pihak swasta untuk saling berinteraksi dan pada akhirnya membentuk habitus baru diluar kebiasaan yang ada selama ini. Jadi, arena adalah ruang khusus yang ada dan dibentuk di dalam masyarakat dimana didalamnya menjadi pertemuan berbagai jenis capital. Capital disini tentu saja adalah pengetahuan dan informasi yang dimiliki oleh masing-masing pihak terkait yang saling berinteraksi di dalam cyber extension sebagai suatu arena. Di dalam ranah itulah terjadi pertaruhan yang mana kekuatan-kekuatan serta orang yang banyak memiliki modal, serta orang yang tidak memiliki modal untuk bisa beroperasi dalam ranah (Takwin, dalam Harker et. al. 2009).

Modal bagi Boudieu dan Fashri (2007) terdapat beberapa jenis modal yang dipertaruhkan dalam arena yakni modal ekonomi, modal sosial, modal budaya dan modal simbolik. Modal dan habitus akan dipertaruhkan dalam sebuah ranah yang merupakan arena kekuasan yang didalamnya terdapat upaya perjuangan untuk memperebutkan sumber daya dan juga untuk memperoleh akses tertentu yang dekat dengan hierarki kekuasaan. Modal akan sangat menentukan seseorang menjadi apa dan mendapat apa dalam cyber extension tersebut. Modal menjadi alat sekaligus tujuan seseorang aktor untuk meraih atau mempertahankan posisi-posisi tertentu.

Disini posisi penyuluh maupun petani dalam arena sangat tergantung pada modal yang dimilikinya. Pada dasarnya modal menurut Bourdeau ada 4 yaitu ekonomi, budaya, sosial, dan simbolik. Pertama, modal ekonomi yang berupa harta kekayaan yang dimiliki petani dan penyuluh. Hal ini berkaitan dengan bagaimana aktor (petani dan penyuluh) memiliki akses untuk berada di dunia cyber. Kepemilikan smartphone, internet, laptop dan alat lain yang menunjang kegiatan cyber extension sudah tentu akan menguatkan posisi aktor dalam arena. Semakin banyak economic capital yang dimiliki maka akses aktor menuju arena juga semakin mudah. Hal ini tentu saja berakibat petani dan penyuluh yang notabene kaya akan lebih mudah mendapat informasi di ruang cyber daripada mereka yang modal ekonomi cenderung rendah. Hal ini terjadi karena modal ekonomi adalah modal yang mudah sekali ditransformasikan menjadi modal-modal yang lain.

Kedua, modal budaya (cultural capital) yang berupa serangkaian kemampuan atau keahlian individu, termasuk di dalamnya pengetahuan, keterampilan, cara bergaul, dan lain-lain yang berperan di dalam penentuan dan reproduksi kedudukan-kedudukan sosial. Jadi disini semakin tinggi pengetahuan dan keterampilan seorang petani dan penyuluh amaka akan semakin mudah pula mereka menyerap informasi dan cepat beradaptasi dengan arenanya. Mereka yang pandai bergaul juga sudah pasti akan memiliki posisi yang lebih menguntungkan dalam cyber extension karena akan lebih mudah dengan ak- 
tor lainnya. Hal ini juga akan berkaitan dengan modal yang ketiga yaitu modal sosial. Modal sosial yang lebih berupa jaringan sosial akan berperan dalam menentukan kedudukan sosial. Semakin banyak kenalan seseorang dan semakin banyak memiliki kesamaan cara pandang, maka semakin kaya modal sosial yang dimilikinya. Karena dengan begitu baik petani maupun penyuluh akan memiliki superioritas dalam ruang cyber daripada mereka yang tidak memiliki jaringan sosial.

Terakhir adalah modal simbolik (symbolic capital), modal ini akan berkaitan dengan kekuatan simbolik yang ada di dalam arena. Missal saja petani yang berpendidikan atau petani kaya serta penyuluh dengan pangkat yang tinggi. Pada dasarnya mereka sudah memiliki modal simbolik ini. Modal yang bisa digunakan oleh mereka untuk memiliki daya jual di dalam kegiatan cyber extension, karena dengan begitu akan banyak orang yang percaya kepadanya. Hingga kemudia interaksi dari keempat modal inilah yang kemudian membentuk arena. Jadi, petani dan penyuluh yang memasuki ranah atau arena tertentu (cyber extension) harus menguasai aturan main untuk bisa eksis di dalamnya. Karena itu, arena atau ranah menjadi medan perjuangan aktor dalam menempatkan dirinya di ruang sosial.

Sedangkan untuk habitusnya, habitus terbentuk secara tidak sadar dalam kehidupan sosial aktor dimana dari sana terjadi interaksi sosial yang bisa menimbulkan kebiasaan dan kebiasaan tersebut menjadi suatu gaya hidup petani dan penyuluh atau kegiatan yang sering dilakukan dalam kehidupan yang di sebut dengan habitus. Sehingga habitus dalam cyber extension ini adalah sebuah kebiasaan yang sudah membudaya diperoleh dari kegiatan-kegiatan dan pengalaman ketika memanfaatkan cyber extension. Habitus penyuluhan yang terbentuk disin seperti berdiskusi, membaca untuk mendapatkan informasi, membagi informasi, mecari informasi dan lain sebagainya, kebiasaan ini menjadi suatu pola kehidupan individu karena pengalaman yang sudah terinternalisasi dalam dirinya sehingga disebut habitus.

Baik penyuluh maupun petani yang aktif di cyber extension akan memiliki habitus belajar di ruang cyber yang berbeda. Akan ada yang menganggap penyuluhan di ruang cyber adalah kebutuhan, dalam hal ini mereka menganggap bahwa proses belajar yang mereka lakukan ada- lah sebagai kebutuhan mereka seperti kebutuhan lainnya sehingga dalam prosesnya kegiatan penyuluhan berjalan alamiah dan kemudian menjadikan kegiatan belajar, mencari, dan berbagi informasi lewat cyber extension sebagai suatu kebiasaan.

Habitus lain yang terbentuk dengan adanya cyber extension tentu saja bagaimana penyuluhan kini tak lagi mengharuskan kegiatan tatap muka dan petani serta penyuluh menjadi lebih senang untuk mencari informasi di ruang cyber. Interaksi yang mereka lakukanpun tak lagi di dunia nyata namun berada di arena baru yang ada di dunia virtual. Proses internalisasi kegiatan penyuluhan di ruang cyber yang berjalan lama dan kemudian tereksternalisasi ulang inilah yang kemudian membentuk habitus mereka. Jadi, habitus disini adalah kebiasaan yang terstruktur secara sendirinya dan tumbuh dalam masyarakat secara alami melalui proses sosial yang sangat panjang, terinternalisasi dan terakulturasi dalam diri masyarakat tani serta penyuluh. Dan interaksi dari berbagai aspek inilah yang kemudian melahirkan praktik sosial baru antara petani dan penyuluh.

Praktik sosial yang dilakukan oleh petani dan penyuluh yang tergabung dalam layanan cyber extension, baik di arena virtual maupun arena nyata kemudian menjadi wujud dari habitus mereka masing-masing tentunya dengan karakteristik mereka yang berbeda-beda dalam menggunakan cyber extension. Praktik sosial ini adalah satu kesatuan yang berasal dari hubungan antara modal dan arena, terjadinya pratik untuk melakukan kegatan belajar seara mandiri lewat cyber extension ini karena melekatnya habitus dalam diri aktor sehingga menjadi kebiasaan yang dilakukan secara berulang-ulang. Melalui praktek inilah penyuluh dan petani yang mengikuti cyber extension dapat menjaga eksistensinya dalam dunia nyata, karena mereka memiliki apa yang tidak dimiliki oleh aktor lainnya.

\section{KESIMPULAN}

Cyber extension merupakan sebuah kegiatan penyuluhan pertanian yang dilakukan di dunia maya. Tak lagi mengikuti pola lama yang mngharuskan petani dan penyuluh bertemu di lapang. Cyber extension berusaha hadir untuk memberikan layanan informasi secara real time, cepat, dan akurat kepada petani. Berbagai kemudahanpun diperoleh dengan adanya cyber extension, seperti penyuluh yang mudah mengem- 
bangkan kompetensinya atau petani yang juga dengan mudah bisa bertukar informasi dengan petani lain di belahan bumi yang berbeda. Penyuluhan yang berbasis teknologi informasi sudah barang pasti juga memberikan banyak perubahan dalam struktur sosial dan budaya masyarakat tani. Perubahan itu ada yang bergerak menuju ke arah positif namun ada juga yang justru cyber extension menyebabkan perubahan ke arah yang negatif. Namun, perubahan itu bukan karena sebab karena memang menurut Castell, teknologi informasi yang berkembang seperti cyber extension hadir dalam rangka untuk memberikan sebuah efek positif bagi kehidupan manusia. Sedangkan Bourdeau memandang cyber extension sebagai suatu arena yang didalamnya terdapat pertarungan modal yang dimiliki oleh petani maupun penyuluh. Sehingga membentuk sebuah habitus baru dan melahirkan praktek yang sosial yang berbeda sebelum adanya kegiatan penyuluhan yang dilakukan di ruang virtual.

Hasil kajian teoritis ini dapat digunakan sebagai arahan untuk penelitian lebih lanjut terkait dengan bentuk-bentuk cyber extention, media yang digunakan, dan juga isi (content) yang ditampilkan.

\section{DAFTAR PUSTAKA \\ Buku}

Arce, A. dan N. Long. 1992. The Dynamics of Knowledge: Interfaces between Bureaucrats and Peasants dalam N. Long dan A. Long. Battlefields of Knowledge: the Interlocking of Theory and Practice in Social Research and Development. London: Routledge.

Bourdieu, Pierre. 1990.The Logic of Practise. California: Stanford University Press.

Bourgeois, R., F. Jesus, M. Roesch, N. Soeprapto, A. Renggana, dan A. Gouyon. 2013. Indonesia: Empowering Rural Producers Organization. Rural Development and Natural Resources East Asia and Pasific Region.

Browning LD, AS Saetre, KK Stephens, and JO Sornes. 2008. Information and Communication Technology in Action. Linking Theory and Narratives of Practice. New York and London: Routledge.

Chambers, R. 1993. Challenging the Professions: Frontiers for Rural Development. London: Intermediate Technology Publications.
Fashri, Fauzi. 2007. Penyingkapan Kuasa Simbol (Apropriasi Reflektif Pemikiran Pierre Bourdieu).Yogyakarta: Juxtapose.

Harker, R. 2009. (Habitus $x$ Modal $)+$ Ranah $=$ Praktik, Pengantar Paling Komprehensif Kepada Pemikiran Pierre Bourdieu. Yogyakarta: Jalasutra.

Jhonson, P. dan Doyel. 1986. Teori Sosiologi Klasik dan Moderen. Diterjemahkan oleh Lawang M.Z Robert. Jakarta: PT. Gramedia.

Kottak, C.P. 1988. Bila Manusia yang Utama: Beberapa Hikmah Sosiologi dari Proyek-Proyek yang Telah Selesai dalam M.M. Cernea (eds). 1988. Mengutamakan Manusia di Dalam Pembangunan: Variabel-variabel Sosiologi di Dalam Pembangunan Pedesaan (Publikasi Bank Dunia). Penerjemah B.B. Teku. Jakarta: UI Press.

Mardikanto, Totok. 1993. Penyuluhan Pembangunan Pertanian. Universitas Sebelas Maret Press. Surakarta.

Rahadian AH. 2010. Manajemen Penyuluhan Pertanian, Perikanan dan Kehutanan. Jakarta: PT. Duta Karya Swasta.

Rhoades, R.E dan A. Bebbington. 1995. Farmers Who Experiment: an Untapped Resource for Agricultural Research and Development dalam D.M. Warren, L.J. Slikkerveer dan D. Brokensha. The Cultural Dimension of Development: Indigenous Knowledge Systems. London: Intermediate Technology Publications.

Sharma, P.V. 2006. Cyber Extension: Information and Communication Technology (ICT) Applications for Agricultural Extension Service Challenges, Oppurtunities, Issues and Strategies. Enhancement of Extension System in Agriculture. APO.

Slamet M. 2003. Paradigma Baru Penyuluhan Pertanian di Era Otonomi Daerah. Dalam Buku Membentuk Pola Perilaku Manusia Pembangunan. Bogor: IPB Press.

Sumardjo L, Baga M, Mulyandari RSH. 2010. Cyber Extension: Peluang dan Tantangan dalam Revitalisasi Penyuluhan Pertanian. Bogor: IPB Press.

Uphoff, N. 1988. Menyesuaikan Proyek pada Manusia. dalam M.M. Cernea (eds). 
1988. Mengutamakan Manusia di Dalam Pembangunan: Variabel-variabel Sosiologi di Dalam Pembangunan Pedesaan (Publikasi Bank Dunia). Penerjemah B.B. Teku. Jakarta: UI Press.

Van Den Ban, A.W. dan H.S. Hawkins, 1999. Penyuluhan Pertanian. Yogyakarta: Kanisius.

\section{Jurnal, Prosiding, dan Makalah}

Adekoya AE. 2007. Cyber extension communication: A strategic model for agricultural and rural transformation in Nigeria. International journal of food, agriculture and environment 5(1): 366-368.

Ahuja V. 2011. Cyber Extension : A Convergence of ICT and Agricultural Development. Global Media Journal Indian Edition 2(2): 1-8.

Alemna AA, dan Joel Sam. 2006. Critical Issues in Information and Communication Technologies for Rural Development in Ghana. Information Development 22(4). SAGE Publications.

Amin, Muhammad. 2014. Efektivitas dan Perilaku Petani dalam Memanfaatkan Teknologi Informasi Berbasis Cyber Extension. Jurnal Informatika Pertanian 23(2): 211-219.

Amin M., Sugiyanto, Sukesi K, Ismadi. 2013. Application of Cyber Extension as Communication Media to Empower the Dry Land Farmer at Donggala District, Central Sulawesi. Journal of Basic and Applied Scientific Research.3(4):379-385.

Anwas, E. Oos M., Sumardjo, Pang S. Asngari, dan Prabowo Tjitropranoto. 2010. Model Pengembangan Kompetensi Penyuluh Berbasis Pemanfaatan Media (Kasus Di Kabupaten Karawang dan Garut, Provinsi Jawa Barat). Jurnal Penyuluhan 6(1): 1-10.

Apriantono, A., 2006. Pembangunan Pertanian di Indonesia. Deptan.

Atrisiandy, Khasril. 2015. Pengembangan Profesionalisme Penyuluh Pertanian Melalui Penguasaan Teknologi Informasi (TI). Balai Pengkajian Teknologi Pertanian Sumatera Utara: 1-33.

Castells, Manuel. 2000. Toward a Sociology of the Network Society. Contemporary Sociology, American Sociological Association 29(5): 693-699.
Damanik, Inta P. N. dan Meilvis E Tahitu. 2011. Cyber Extension Dan Model Sistem Penyuluhanpertanian Untuk Menjawab Tantangan Pembangunan Pertanian Di Maluku-Suatu Pemikiran. Prosiding Seminar Nasional Pengembangan Pulau-Pulau Kecil: 130-136.

Elian, Novi, Djuara P Lubis, dan Parlaungan A Rangkuti. 2014. Penggunaan Internet dan Pemanfaatan Informasi Pertanian oleh Penyuluh Pertanian di Kabupaten Bogor Wilayah Barat. Jurnal Komunikasi Pembangunan 12(2):104-109.

Fatimah, Sri. 2013. Menuju Sumberdaya Penyuluhan Pertanian Tanggap Perubahan: Kasus Implementasi Cyber Extension Di Kabupaten Sumedang. Prosiding Seminar Nasional Peranan Teknologi dan Kelembagaan Pertanian dalam Mewujudkan Pembangunan Pertanian yang Tangguh dan Berkelanjutan: 196205.

Hafsah, Mohammad Jafar. 2009. Penguatan Peran PAPPI dalam Mendukung Tumbuh dan Berkembangnya Modal Sosial di Masyarakat. Makalah Simposium dan Kongres Perhimpunan Ahli Penyuluhan Pembangunan Indonesia (PAPPI). Bogor.

Herlina. 2014. Interaksi Sosial Penyuluh Pertanian Sebagai Upaya Peningkatan Usahatani Masyarakat Petani Di Kabupaten Batang. Journal of Educational Social Studies 3 (2): 30-37.

Mulyandari, R. S. H. Sumardjo, D. P. Lubis, dan N. K. Pandjaitan. 2010. Analisis Sistem Kerja Cyber Extension Mendukung Peningkatan Keberdayaan Petani Sayuran. Jurnal Komunikasi Pembangunan 8(2): 1-16.

Mulyandari, Retno S.H. 2011. Perilaku Petani Sayuran dalam Memanfaatkan Teknologi Informasi. Jurnal Perpustakaan Pertanian 20(1): 22-34.

Pranadji, T. 1995. Wirausaha, Kemitraan Dan Pengembangan Agribisnis Secara Berkelanjutan. Analisis Center of Strategic and International Studies 14(5): 332-343.

Rangkuti, P.A. 2010. Peran Komunikasi dalam Modernisasi Pertanian Berbasis Koperasi. Jurnal Komunikasi Pembangunan 8(1): 1-7. 
Reddy, Deva E. 2005. Using The Four Ds Model Of Agricultural Information Transfer To Study The Impact Of Digital Information Sources. Quarterly Bulletin of the International Association of Agricultural Information Specialists. 50: (3/4).

Severin, J W. T. Jr. 2009. Teori Komunikasi. Sejarah, metode dan Terapan di dalam Media Massa. Edisi Kelima. Jakarta Kencana: 443-465.

Suryantini H. 2004. Kebutuhan Informasi Dan Motivasi Kognitif Penyuluh Pertanian Serta Hubungannya Dengan Penggunaan Sumber Informasi (Kasus Di Kabupaten Bogor, Jawa Barat). Jurnal Perpustakaan Pertanian. 12(2): 33-41.

Subejo. 2011. Babak Baru Penyuluhan Pertanian dan Pedesaan. Jurnal Ilmu-Ilmu Pertanian 7(1): 61-70.

Usman, J.M, Adeboye, J. A, Oluyole, K. A, dan Ajijola, S. 2012. Use of Information and Communication Technologies by Rural Farmers in Oluyole Local Government Area of Oyo State, Nigeria. Journal of Stored Products and Postharvest Research 3(11): 156-159.

\section{Skripsi/Thesis/Disertasi}

Anwas, Oos M. 2009. Pemanfaatan Media dalam Pengembangan Kompetensi Penyuluh Pertanian. [Disertasi]. Bogor: Institut Pertanian Bogor.

Mulyandari R.S.H. 2011. Cyber Extension Sebagai Media Komunikasi Dalam Pemberdayaan Petani Sayuran. [Disertasi]. Bogor: Institut Pertanian Bogor.

Sumardjo. 1999. Transfomasi Model Penyuluhan Pertanian Menuju Pengembangan Kemandirian Petani. [Disertasi]. Bogor : Institut Pertanian Bogor. 